\title{
Progesterone in Human Pregnancy and Parturition
}

\author{
Ylva Vladic Stjernholm \\ Department of Woman and Child Health, \\ Karolinska University Hospital and Institute, Stockholm, \\ Sweden
}

\section{Introduction}

\subsection{Progesterone synthesis}

Progesterone was independently discovered by different research groups (Butenandt \& Westphal 1934, Allen 1935). Allen and collaborators discovered progesterone in 1933, and were the first to determine the molecular weight and partial molecular structure. The name progesterone derives from progestational steroidal ketone (Allen 1935).

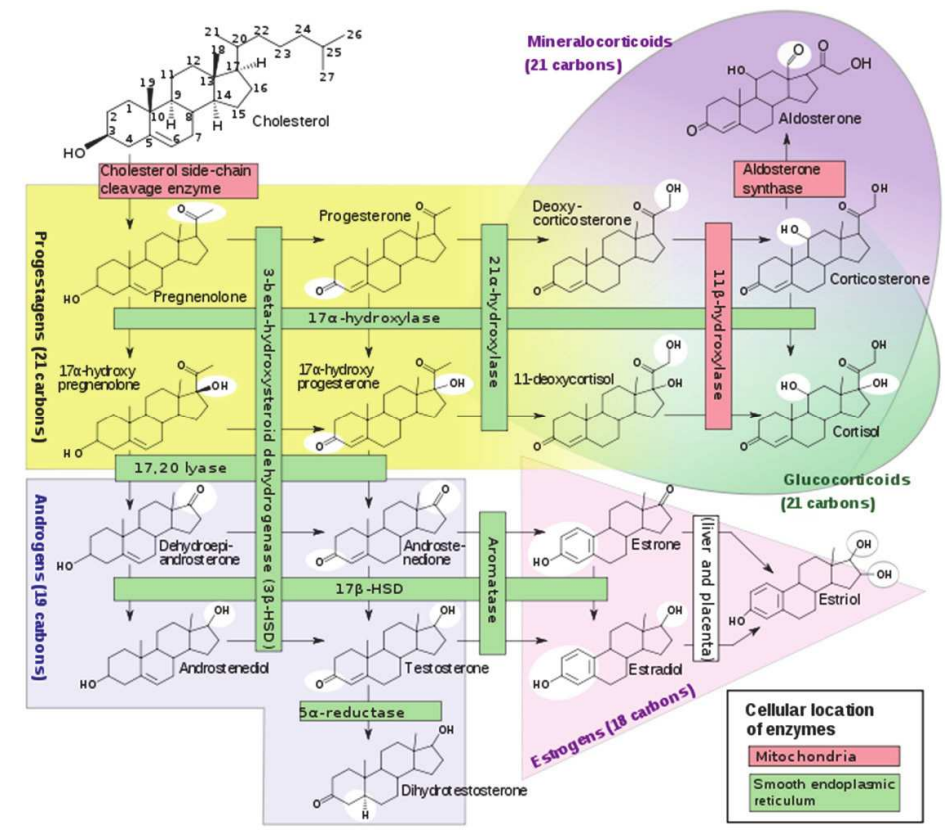

Fig. 1. Steroid hormone synthesis. The precursor cholesterol from the maternal circulation is converted to 21 carbon (C21) progestagens. Progestagens can be converted to C21 glucocorticoids, or to C19 androgens. Androgens serve as precursors for C18 estrogens. Source: Wikipedia. 
Progesterone belongs to the C21 group of progestagens and is the evolutionary most conserved of the reproductive steroid hormones. The synthesis of progesterone from its precursor cholesterol in the maternal circulation requires only two enzymatic steps to form pregnenolone, which is readily transformed to progesterone. The main source of progesterone in humans is the corpus luteum in the ovary. After conception, the corpus luteum is supported by the secretion of human chorionic gonadotropin (hCG) from the conceptus, and produces progesterone until approximately the $10^{\text {th }}$ gestational week. After a transition period by 7-10 gestational weeks the placenta becomes the major progesterone source, using circulating cholesterol as a substrate, after which maternal serum levels of progesterone increase markedly. Progesterone in serum is to $95-99 \%$ bound to corticosteroid binding globulin (CBG) almost as tightly as glucocorticoids (Speroff et al 1994).

Progesterone accompanies and modulates estrogen action. Whereas progesterone is synthesized in the placenta, neither the placenta nor the fetal adrenal glands are capable of producing sufficient quantities of precursors for estrogen synthesis. This observation led to the coining of the unique endocrine system "the maternal-fetal-placental unit" (Diczfalucy 1969). In early pregnancy, the maternal circulation provides androgen precursors for estrogen synthesis. By 20 gestational weeks the majority of androgen precursors, predominantly dehydroepiandrosterone sulphate (DHEAS), are derived from the fetal adrenals. The fetal compartment is extremely efficient in sulphate conjugation of steroid hormones, protecting the fetus from high steroid concentrations. About $30 \%$ of circulating estrogens are loosely bound to albumin, whereas the major amount is tightly bound to sex hormone binding globulin (SHBG) (Speroff et al 1994).

\section{Mechanisms of action}

\subsection{Genomic effects}

The nuclear progesterone receptor (nPR) belongs to the steroid supergroup of transcription factor proteins (O’Malley et al 1990). All steroid receptor proteins are composed of a variable $\mathrm{N}$-terminal domain which activates gene transcription and protein-protein interactions, determining the biological response of the steroid, an evolutionary highly conserved DNAbinding domain, a flexible hinge region and a C-terminal ligand-binding domain. The classic genomic mechanism of steroid action involving mRNA and protein synthesis is slow, occurring over hours to days.

The nPR binds to progesterone, and with a much less affinity to cortisol (Sanborn et al 1976). The biological response to progesterone is dependent on the levels and ratios of the nPR isoforms. The $\mathrm{nPR}$ isoforms A (nPR-A) $(94 \mathrm{kDa})$ and $\mathrm{nPR}-\mathrm{B}(116 \mathrm{kDa})$ are transcribed from the same gene, being activated by different promoters. The nPR-B isoform contains an additional 164 amino acids at the $\mathrm{N}$-terminal and activates progesterone responsive genes. The nPR-A isoform is a weaker activator of transcription than nPR-B and can act as an inhibitor of nPR-B and other steroid receptors such as the nuclear estrogen (nER) and nuclear glucocorticoid (nGR) receptors (Vegeto et al 1993, Pieber et al 2001). A third nPR-C isoform has been identified in human myometrium (Condon et al 2006). nPR-C lacks a large segment of the N-terminal and a major part of the DNA-binding domain, and therefore cannot bind to DNA. 


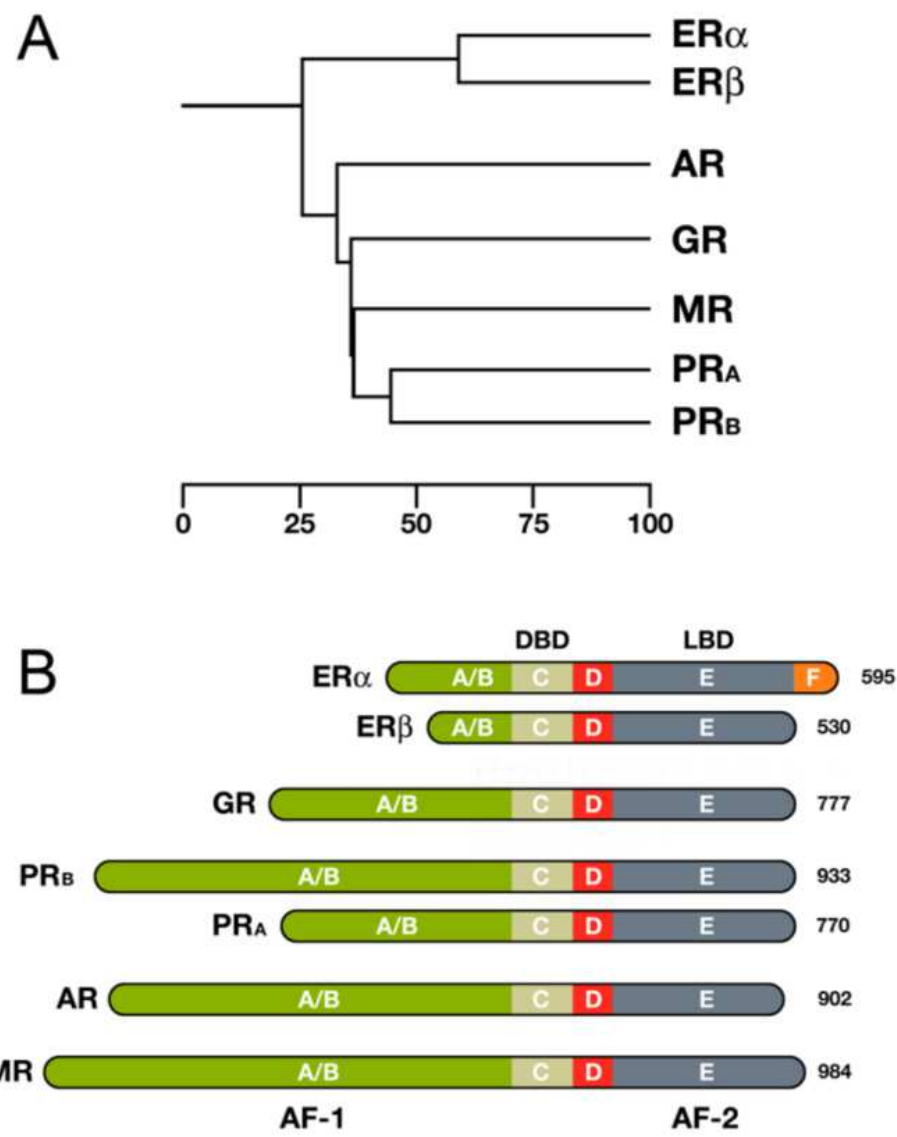

Fig. 2. The steroid hormone receptor family. A. Phylogenetic tree of the steroid hormone receptors showing the evolutionary interrelationships between the receptors . B. Sequence homologies of intracellular steroid hormone receptor proteins showing the $\mathrm{N}$-terminal domain (A/B), the DNA-binding domain (DBD, C), the hinge region (D) and the C-terminal ligand binding domain (LBD, E). The human estrogen receptor subtypes (ER $\alpha$ and ER $\beta$ ), glucocorticoid receptor (GR), progesterone receptor isoforms (PRA and PRB), androgen receptor (AR), and mineralocorticoid receptor (MR) are described. The estrogen receptor $\alpha$ is unique in that it contains an additional C-terminal F domain. Numbers represent the amino acid sequency of the receptors. In Griekspoor A, et al. Nuclear Receptor Signaling (2007) 5, e003.

\subsection{Non-genomic effects}

Steroid hormones have been shown to initiate rapid actions, which cannot be explained by the slow genomic mechanisms. Such rapid actions occur within seconds through the activation of intracellular signaling pathways resulting in alterations in ion fluxes and intracellular free calcium concentrations (Blackmore et al 1991), and within minutes through the activation of other second messengers, such as cyclic nucleotides and extracellular- 
regulated kinase (ERK) 1 and 2 (Filardo et al 2000). Recently, three new putative membrane progesterone receptors ( $\mathrm{mPRs}$ ), $\mathrm{mPRa}, \mathrm{mPR} \beta$, and $\mathrm{mPR} \gamma$ were identified in humans (Zhu et al 2003).

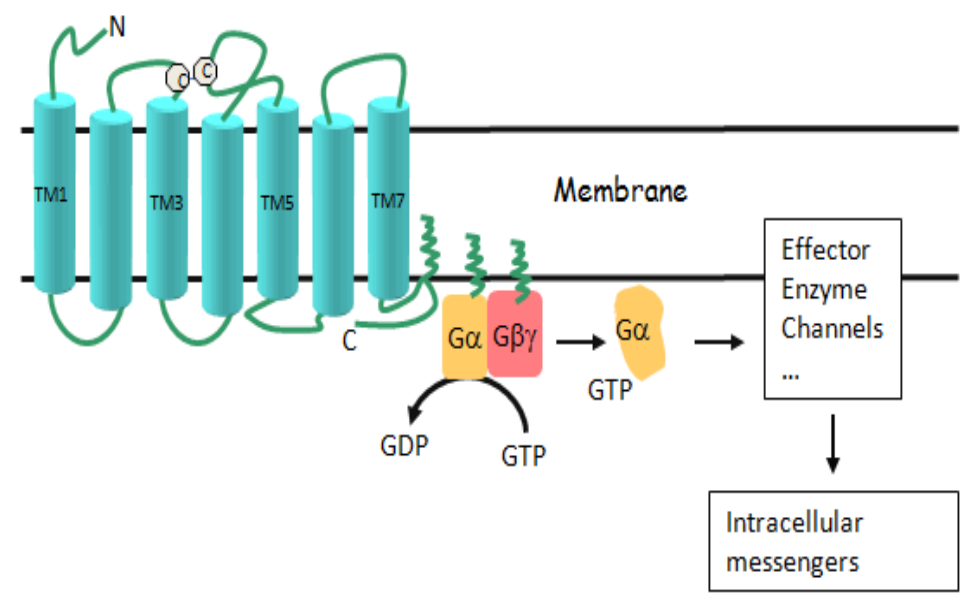

Fig. 3. G (guanine nucleotide-binding) protein-coupled transmembrane (TM) receptors communicate signals from hormones and other signaling factors to intracellular messengers. They consist of the $\mathrm{G} \alpha$ and the tightly associated $\mathrm{G} \beta, \gamma$ subunits. Here guanosinetriphosphate (GTP) is hydrolyzed by Ga subunit to guanosine-diphosphate (GDP). Source: CellMosaic, Worcester, MA, US.

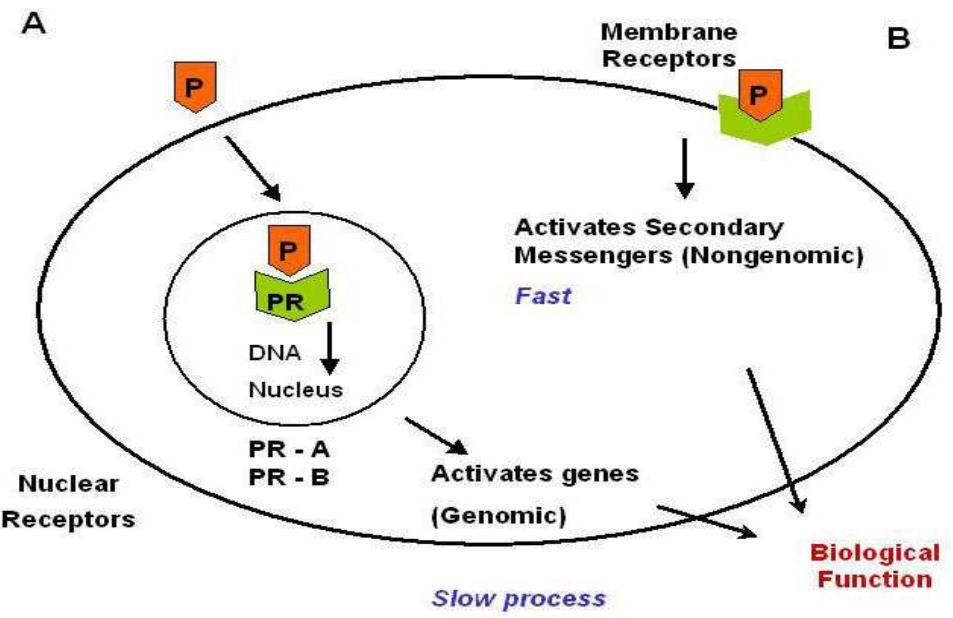

Fig. 4. Nuclear and transmembrane-bound progesterone receptors mediating genomic and non-genomic effects. Progesterone (P) activates A. Genomic pathways through nuclear receptor proteins (PR-A, PR-B) resulting in gene activation (slow process) and/or B. Nongenomic pathways via membrane-bound receptors, which activate secondary messengers (fast process). 


\section{Systemic effects}

Serum levels of progesterone increase progressively during human pregnancy and remain high until delivery of the placenta (Csapo et al 1973, Speroff et al 1994, Stjernholm et al 1997). In other species, such as rodents and rabbits, which depend on an active corpus luteum for progesterone synthesis throughout pregnancy, labor is initiated by prostaglandin $\mathrm{F}_{2} \alpha\left(\mathrm{PG}-\mathrm{F}_{2} \alpha\right)$ from the endometrium, activating prostaglandin $\mathrm{F}(\mathrm{FP})$-receptors in the corpus luteum leading to luteolysis (Sugimoto et al 1997). These observations led to the concept of a "functional progesterone withdrawal" at parturition in humans (Hertelendy \& Zakar 2004).

\subsection{The placenta}

Placental concentrations of progesterone reach 1-10 $\mu \mathrm{M}$ (Stites $\mathcal{E}$ Siiteri 1983, Miyaura E Iwata 2002), whereas serum concentrations reach $100-500 \mathrm{nM}$ until term pregnancy before labor (Stjernholm et al 1997; Miyaura \& Iwata 2002).

\subsection{The vascular system}

Increased levels of prostacyclin $\left(\mathrm{PGI}_{2}\right)$ are considered to be a factor behind the physiological angiotensin resistance observed in normal pregnancy (Friedman 1988). A progesterone induced mechanism behind this refractoriness to angiotensin has been suggested (Everett et al 1978, Rupnow et al 2002). Nitric oxide (NO) and protein kinase C (PKC) pathways are involved in the regulation of vascular tone during pregnancy (Kublickiene et al 1997, Chang et al 2008).

\subsection{The respiratory system}

The pulmonary function is not impaired by pregnancy, but the tidal volume, minute ventilator volume and minute oxygen uptake increase with advancing gestation. This pregnancy-induced respiratory alkalosis is partially compensated for by increased renal excretion of bicarbonate. As a consequence, maternal arterial $\mathrm{pH}$ is increased to 7.46. The increased respiratory effort and decrease in $\mathrm{PCO}_{2}$ has been related to progesterone and to a lesser degree to estrogen (Wolfe et al 1998, Jensen et al 2005).

\section{The uterus}

\subsection{The decidua at implantation}

Successful maintenance of pregnancy depends on maternal tolerance of the fetal semiallograft (Szekeres-Bartho 2002). Progesterone, cortisol and prolactin have strong immunomodulatory effects leading to immunotolerance during pregnancy (Stites \& Siiteri 1983, Speroff et al 1994). The human decidua is adjacent to the myometrium, the fetal trophoblasts of the placenta and to the fetal membranes. Natural killer (NK) cells is the predominant immune cell in the decidua before implantation and in early pregnancy, constituting $70 \%$ of decidual immune cells, followed by macrophages constituting about $10 \%$ of total decidual cells, dendritic cells (DC) and T lymphocytes. The local endocrine environment regulates the recruitment of monocytes into the uterus, and the subsequent differentiation of monocytes into macrophages with specific phenotypes promoting immunotolerance or inflammation (Stout et al 2004). Colony-stimulating factor (CSF)-1, macrophage migration inhibitory factor (MIF), monocyte chemoattractant protein (MCP)-1 and regulated on activation, normal T cell expressed, and secreted (RANTES) have been 
suggested as factors involved in the recruitment and modulation of decidual macrophages, and are synthesized by decidual stromal cells, NK-cells and trophoblasts at the maternalfetal interface (Wood et al, 1997; Lockwood et al 2006). Resident decidual macrophages appear to express immunosuppressive actions that favor the maintenance of pregnancy. In contrast, monocytes/macrophages migrating into the lower uterine segment prior to parturition are involved in the inflammatory process associated with cervical ripening and labor initiation (Nagamatsu et al 2010). A switch in decidual type 1 (Th1) to type 2 (Th2) T cell dominance in the fetal-placental interface has been suggested to play a crucial role in the establishment of pregnancy (Wegmann et al 1993). Human Th1 T-cells are the main effectors of host defence and Th1-type cytokines produce proinflammtory responses. The Th- 1 response involves interferon (IFN)- $\gamma$, interleukin-2 (IL-2), tumor necrosis factor (TNF)- $\alpha$, and the generation of cell-mediated immunity. On the contrary, human Th2 T cells inhibit macrophage functions. A Th2 response involves IL-4, IL-5, anti-inflammatory IL-10, IL-10, IL-13, and the stimulation of humoral immunity (Abbas et al 1996, Weiner et al 2001).

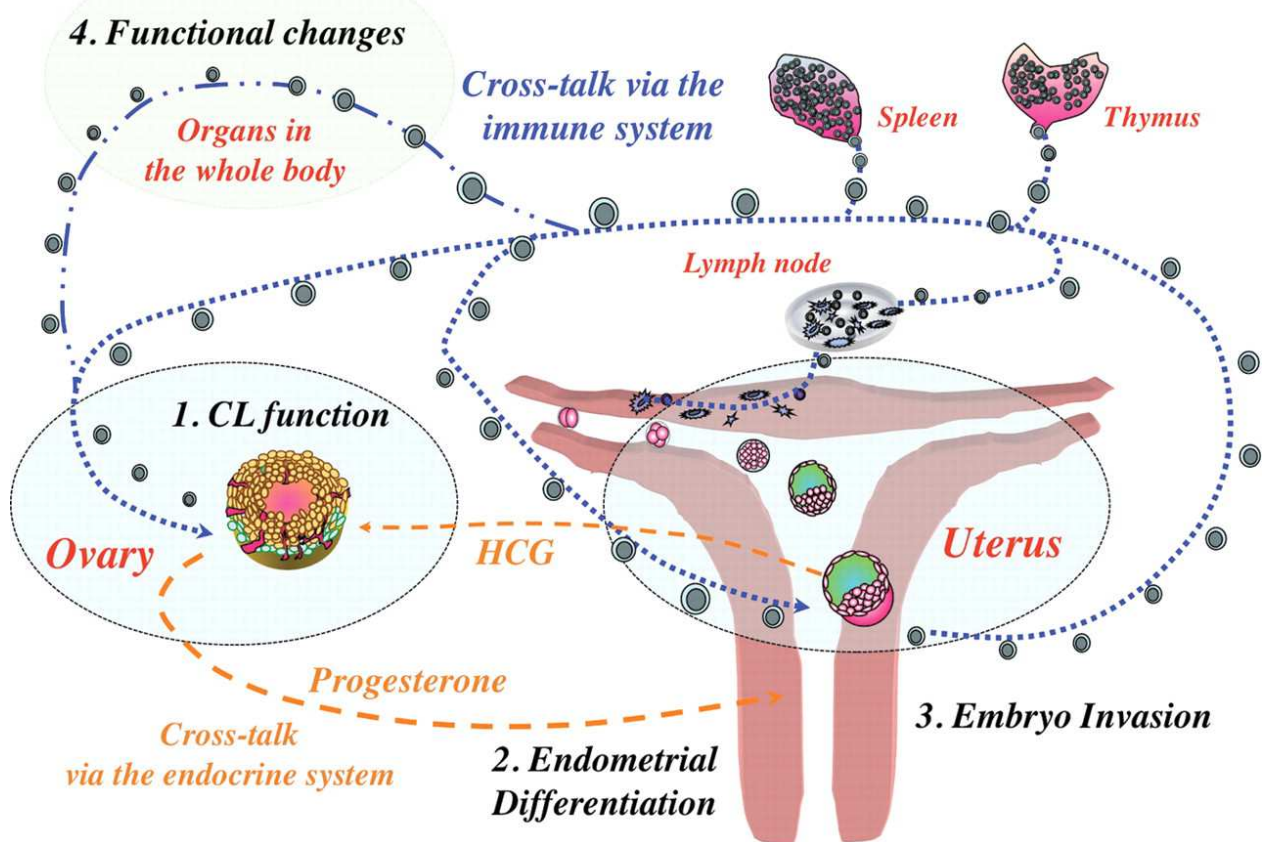

Fig. 5. Endocrine and immune cross-talk in the fetal-maternal interface at implantation. $\mathrm{CL}=$ corpus luteum, HCG= human chorionic gonadotropin. In Fujiwara H. Molecular Human Reproduction (2009) 15, 335-343.

Progesterone at concentrations higher than in serum but comparable to those in the maternal-fetal interface induces differentiation of T cells along the Th2 pathway (Stites $\mathcal{E}$ Siiteri 1983; Piccinni et al 1995, Miyaura E Iwata 2002). Glucocorticoids and 1,25-dihydroxy Vitamin D increase IL-4 (Rook et al 1994), whereas dihydrotestosterone decreases IL-4 and IL-5 production (Vacca et al 1990). 
The progesterone induced protective immune environment in the decidua during early pregnancy includes production of the immunomodulatory progesterone-induced blocking factor (PIBF) protein by decidual cells (Szekeres-Bartho et al 1985, Piccinni et al 1995). The presence of nPRs in immune cells has been debated. nPRs in the thymus are necessary for progesterone induced involution of the thymus during pregnancy (Tibbetts et al 1999). Most studies have showed an absence of nPRs in lymphocytes from nonpregnant women (Szekeres-Bartho et al 1990, Mansour et al 1994, Bamberger et al 1999). Recently, transcripts for $\mathrm{mPR} \alpha$ and $\mathrm{mPR} \beta$ but not $\mathrm{mPR} \gamma$, were detected in human peripheral blood leukocytes and $\mathrm{T}$ lymphocytes. Progesterone activated an inhibitory G-protein (Gi), suggesting that $\mathrm{mPRs}$ are coupled to Gi. These results suggest a potential novel mechanism for progesterone's immunoregulatory function through activation of mPRs (Dosiou et al 2008).

The establishment of human pregnancy is associated with an adequate synthesis of leukemia inhibitory factor (LIF), and macrophage colony-stimulating factor (M-CSF) producing T-cells. Progesterone at concentrations comparable to those in the maternal-fetal interface induces LIF and M-CSF (Piccinni 2010).

\subsection{The myometrium}

The corpus uteri is a muscular organ with about $70 \%$ smooth muscle cells surrounded by extracellular matrix (Danforth 1954). Progesterone is holding the uterine myometrium in a quiescent state, "a progesterone block", during pregnancy by suppressing the propagation of electrical activity between the excitable myocyte membranes (Csapo 1956, Csapo et al 1973). The genomic and nongenomic pathways co-operate to maintain myometrial relaxation. At parturition, a functional progesterone withdrawal occurs by increased expression of the $\mathrm{nPR}-\mathrm{A}$ and/or $\mathrm{nPR}-\mathrm{C}$ to $\mathrm{nPR}-\mathrm{B}$ ratios and changes in $\mathrm{nPR}$ co-regulator levels which result in repression of the nPR-B transcriptional activity. The diminished progesterone influence leads to an estrogen dominance (Mesiano et al 2002). Prostaglandins have been shown to induce an increased nPR-A/nPR-B ratio through the protein kinase $C$ (PKC) pathway in human myometrial cells (Madsen et al 2004). Proinflammatory IL-1 $\beta$ up-regulates nPR-C in human myometrial cells, leading to diminished activation of nPR-B (Condon et al 2006). The increased expression of specific membrane-associated PRs (mPRs) at parturition augments contractility by decreasing intracellular cyclic adenosine monophosphate (cAMP) and altering intracellular $\mathrm{Ca}_{2+}$ levels. (Pieber et al 2001, Mesiano et al 2002, Madsen et al 2004, Mesiano 2007).

\section{The cervix uteri}

The cervix uteri is up to $85 \%$ composed by connective tissue, which is dominated by collagen fibers. Fibroblasts, smooth muscle cells, T and B lymphocytes, leukocytes and Langerhans cells are scattered within the tissue (Danforth \& Evanston 1954, Schwalm \& Dubrauszky 1966, White et al 1997). Cervical remodeling is a prerequisite for cervical effacement and dilatation prior to labor and is characterized by increased levels of vascular adhesion molecules (VCAM), diapedesis and activation of neutrophils, monocytes/macrophages, $\mathrm{T}$ lymphocytes, mast cells, eosinophils, the release of proinflammatory cytokines such as IL-1 $\beta$ and the strong chemotactor IL-8, and increased tissue concentrations of metalloproteinase enzymes (MMPs) (Junquiera et al 1980, Liggins 1981, Uldbjerg et al 1983, Bokström et al 1997, Sennström et al 2000, Stygar et al 2002, Winkler et al 2003). At parturition, a functional progesterone withdrawal occurs in the cervix uteri with decreased total $\mathrm{nPR}$ and an increased nPR-A/nPR-B ratio 
(Stjernholm et al 1997, Vladic Stjernholm et al 2004). These endocrine and inflammatory events are followed by an up to $30-50 \%$ decreased collagen concentration, and an altered proteoglycan composition with a decreased density of the small proteoglycan decorin and an increased density of the large proteoglycan Versican. These events result in dispersed collagen fibrils clinically recognized as cervical effacement and dilatation (Uldbjerg et al 1983, Ekman et al 1986, Norman et al 1993, Stjernholm et al 1997). Evidence suggest that progesterone effects on the cervix uteri are even more pronounced than its effects on the myometrium (Romero 2007).

\section{Cervical Effacement}
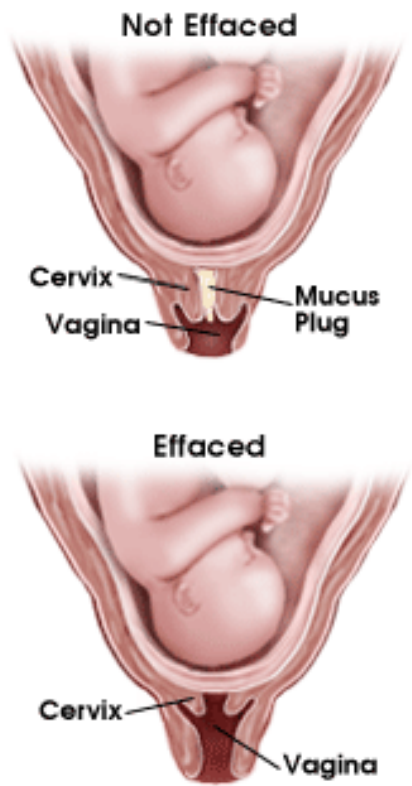

Fig. 6. Cervical effacement and dilatation before labor onset.

\section{Parturition}

\subsection{Animal studies}

Classical experiments in sheep demonstrated that parturition in this species is initiated by activation of the fetal hypothalamic pituitary adrenal (HPA) axis leading to increased fetal cortisol secretion and induction of placental P450 enzymes (17 $\alpha$-hydroxylase and 17-20-lyase activities), which favor the conversion of C21 to C18 steroids (Liggins 1974, Anderson et al 1975).

\subsection{Human parturition}

Progesterone is the main progestational hormone in humans, whereas the HPA axis has a modulatory function (Hertelendy \& Zakar 2004). Prostaglandins (PGs) from the E and F series are considered to be the main promoters of cervical ripening and myometrial contractility, and the influence of $\mathrm{PG}-\mathrm{E}_{2}$ in promotion of cervical maturation and uterine vasodilatation has been 
suggested as the primary functions of PGs in human parturition (Hertelendy E Zakar 2004). Human decidual macrophages synthetize PGs (Norwitz 1991). Mechanical stretch of the lower uterine segment, proinflammatory cytokines such as IL-1 $\beta$ and the peptide hormone oxytocin induce PG synthesis (Molnar et al 1999, Allport et al 2001, Leguizamon et al 2001).

Successful treatment with PG- $\mathrm{E}_{2}$ for cervical priming before labor induction, allowing for resulting in cervical effacement and dilatation allowing for parturition was associated with diminished cervical progesterone and androgen receptor concentrations (Vladic Stjernholm, 2009).

\section{The puerperium}

After delivery of the placenta, serum concentrations of estrogen and progesterone decrease within hours, and the puerperuim (puer: infant, pario: give birth) is a hypoestrogenic and hypoprogestagenic state. The high progesterone level during pregnancy inhibits lactation. The fall in progesterone levels after delivery is one factor that stimulates milk production (Tucker 1979).

\section{Progestin and progesterone treatment}

Natural progesterone and synthetic progestins do both exert a progestogenic effect, defined as the decidualizing effect on estrogen-primed rabbit endometium (Elton 1966, Schindler et al 2003).

\subsection{Progestins and progesterone for preventing miscarriage}

In clinical practice, progestin treatment was practised since the 1950s as luteal phase support to prevent miscarriage during the first trimester of pregnancy. The amount of data from wellcontrolled clinical trials is limited. Further studies are required to establish the optimal treatment situation as well as type and dose of progestin (LeVine et al 1964, Daya \& Gunby 2004).

\subsection{Progestins and progesterone for preventing premature birth}

Since the 1960s studies on treatment with synthetic progestins for preventing premature childbirth have reported beneficial effects. Human pregnancy lasts 40 gestational weeks and birth between 22 and 37 weeks is defined as premature (WHO 1977). The highly active progesterone ester $17 \alpha$-hydroxyprogestrone caproate has a long duration allowing for

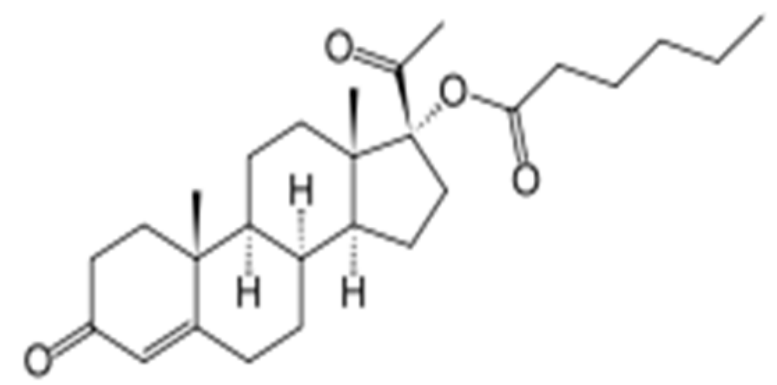

Fig. 7. The synthetic progestin $17 \alpha$-hydroxyprogesterone caproate. 
intramuscular administration 1-3 times weekly. It has been administered to risk groups with previous recurrent abortions or previous premature births and to patients with premature contractions and short cervices (Johnsson et al 1976, Meis et al 2003, Dodd et al 2006). Natural progesterone has been administered as of vaginal gel to such risk groups and in situations with premature contractions and short cervices (daFonseca et al 2003, deFranco et al 2007, $O^{\prime}$ Brien et al 2007). Reduced incidence of premature birth before 32, 34 and 37 gestational weeks and improved neonatal outcome were reported (Brent 2005). Further studies are required to establish the optimal dose and type of agent as well as long term effects on the newborn.

\section{Summary}

Progesterone is the evolutionary most conserved of the reproductive steroid hormones. It is the main progestational hormone in humans, and its strong immunomodulatory effects are important for the physiological immunotolerance at implantation. After a transition period by 7-10 gestational weeks the placenta becomes the major progesterone source. Placental concentrations of progesterone reach $1-10 \mu \mathrm{M}$ and serum concentrations 100-500 nM until term pregnancy. Progesterone exerts its effects through genomic nuclear receptor mediated and non-genomic transmembrane receptor mediated processes, keeping the myometrium in a quiescent state and stabilizing the cervix uteri during pregnancy. A functional progesterone withdrawal occurs at human parturition with a diminished total receptor density and altered isoform ratios. In clinical practice, progestin treatment has been given as luteal phase support to prevent miscarriage during the first trimester of pregnancy. Treatment with synthetic progestins and natural progesterone has been shown to reduce the incidence of premature birth. Further studies are required to establish the optimal dose and type of agent as well as long term effects on the newborn.

\section{Acknowledgements}

I thank the editor for inviting me to present this work and Dr Tomislav Vladic for critical comments.

\section{References}

Abbas AK, Murphy KM \& Sher A (1996) Functional diversity of helper T lymphocytes. Nature 383:787-793.

Allen WM (1935) The isolation of crystalline progestin. Science 82 (2118): 89-93.

Allport VC, Pieber D, Slater R, Newton JO, White PR \& Bennett PR (2001) Human labour is associated with nuclear factor-kappaB activity which mediates cyclo-oxygenase-2 expression and is involved with the "functional progesterone withdrawal". Mol Hum Reprod 7:581-586.

Anderson AB, Flint AP \& Turnbull AC (1975) Mechanisms of action of glucocorticoids in induction of ovine parturition: effects on placental steroid metabolism. J Endocrinol 66:61-70. 
Bamberger CM, Else T, Bamberger AM, Beil FU \& Schulte HM (1999) Dissociative glucocorticoid activity of medroxyprogesterone acetate in normal human lymphocytes. J Clin Endocrin Metab 84:4055-4061.

Blackmore PF, Neulen J, Lattanzio F \& Beebe SJ (1991) Cell surface-binding sites for progesterone mediated calcium-uptake in human sperm. J Biol Chem 266:1865518659.

Bokström H, Brännström H, Alexandersson M \& Norström A (1997) Leukocyte subpopulations in cervical stroma at early and late pregnancy. Hum Reprod 12:586-590.

Brent RL (2005) Nongenital malformations following exposure to progestational drugs. The last chapter of an erroneous allegation. Birth Defects Res 73: 906-918.

Butenandt A \& Westphal U (1934) Zur Isolierung und Charakterisierung des CorpusluteumHormons. Berichte Deutsche Chemische Gesellschaft 67:1440-1442.

Chang K \& Zhang L (2008) Steroid hormones and uterine vascular adaptation to pregnancy. Reprod Sci 15: 336-348.

Condon JC, Jeyasuria P, Faust JM \& Mendelson CM (2004) Surfactant protein secreted by the maturing mouse fetal lung acts as a hormone that signals the initiation of parturition. Proc Natl Acad Sci USA 101:4978-4983.

Csapo AI (1956) A progesterone block. Am J Anat 98:273-291.

Csapo AI, Pulkkinen MO \& Wiest WG (1973) Effects of lutectomy and progesterone replacement therapy in early pregnant patients. Am J Obstet Gynecol 115:759765.

Danforth DN \& Evanston MD. The distribution and functional activity of the cervical musculature (1954) Am J Obstet Gynecol 68:1261-1271

Daya S \& Gunby J (2004) Luteal phase support in assisted reproduction cycles (review). Cochrane Database Syst Rev 2:CD004830. Update in: Cochrane Database Syst Rev 2008; (3):CD004830.

da Fonseca EB, Bittar RE, Mario HB \& Zugaib M (2003) Prophylactic administration of progesterone by vaginal suppository to reduce the incidence of spontaneous preterm birth in women at increased risk: a randomised placebo controlled double blind study. Am J Obstet Gynecol 188:419-24.

deFranco EA, O’Brien JM, Adair CD,Lewis DF, Hall DR, et al (2007) Vaginal progesterone is associated with a decrease in risk for early preterm birth and improved neonatal outcome in women with a short cervix: a secondary analysis from a randomized, double-blind, placebo-controlled trial. Ultrasound Obstet Gynecol 30:697-705.

Diczfalucy E (1969) Steroid metabolism in the human feto-placental unit. Acta Endocrinol 61:649-664.

Dodd JM, Flenady V \& Cincotta R (2006) Prenatal administration of progesterone for preventing preterm birth (Review). Cochrane Database Syst Rev CD004947.

Dosiou C, Hamilton AE, Pang Y, Overgaard MT, Tulac S, Dong J, et al (2008) Expression of membrane progesterone receptors on human $\mathrm{T}$ lymphocytes and Jurkat cells and activation of G-proteins by progesterone. J Endocrinol 196:67-77. 
Ekman G, Malmström A, Uldbjerg N \& Ulmsten U (1986) Cervical collagen. An important regulator of cervical function in term labor. Obstet Gynecol 67:663-666.

Elton RL (1966) The decidual cell responses in rabbits. Acta Endocrinol (Copenh) 51:543-550.

Everett RB, Worley RJ, MacDonald PC \& Gant NF (1987) Modification in vascular responsiveness to angiotensin II in pregnant women by intravenously infused $5 \alpha$ dihydroprogesterone. Am J Obstet Gynecol 131:352.

Filardo EJ, Quinn JA, Bland KI \& Frackelton AR (2000) Estrogen-induced activation of ERK1 and ERK-2 requires the G protein-coupled receptor homolog, GPR30, and occurs via trans-activation of the epidermal growth factor receptor through release of HBEGF. Mol Endocrinol 14:1649-1660.

Fonseca EB, Celik E, Parra M, Singh M \& Nicolaides KH (2007) Progesterone and the risk of preterm birth among women with a short cervix. New England J Med 357 (5): $462-$ 469.

Friedman SA (1988) Preeclampsia: A review of the role of prostaglandins. Obstet Gynecol 71:122-137.

Hertelendy F \& Zakar T (2004) Prostaglandins, the myometrium and the cervix. Prostagl, Leukot Essen Fatty Acids 70:207-222.

Jensen D, Wolfe LA, Slatkovska L, Webb KA, Davies GA \& O'Donnell D (2005) Effects of human pregnancy on the ventilatory chemoreflex response to carbon dioxide. Am J Physiol Regul Integr Comp Physiol 288:1369-75.

Johnson JW, Austin KL, Jones GS, Davis GH \% King TM (1975) Efficacy of $17 \alpha$-hydroxyprogestrone caproate in the prevention of premature labour. New Engl J Med 293:675-680.

Junquiera LCU, Zugaib M, Montes G, Toledo O, Krisztan R \& Shigihara K (1980) Morphologic and histological evidence for the occurrence of collagenolysis and for the role of leukocytes during cervical dilatation. Am J Obstet Gynecol 138:273-281.

Kublickiene KR, Nisell H, Poston L, Krüger K \& Lindblom B (2000) Modulation of vascular tone by nitric oxide and endothelin 1 in myometrial resistance arteries from pregnant women at term. Am J Obstet Gynecol 182:87-93.

Leguizamon G, Smith J, Younis H, Nelson DM \& Sadovsky Y (2001) Enhancement of amniotic cyclooxygenase type 2 activity in women with preterm delivery associated with twins or polyhydramnios. Am J Obstet Gynecol 184:117-122.

LeVine L (1964) Habitual abortion. A controlled clinical study of progestational therapy. West J Surg Gynecol 72: 30.

Liggins GC (1974) Parturition in the sheep and the human. Basic Life Sci 4:423-443.

Liggins GC (1981) Cervical ripening as an inflammatory reaction. In The Cervix in pregnancy and labour. Eds: Ellwood DA, Anderson ABM, Edinburg, Scotland, UK. Churchill Livingstone pp 1-9.

Lockwood CJ, Matta P, Krikun G, Koopman LA, Masch R, Toti P, et al (2006) Regulation of monocyte chemoattractant protein-1 expression by tumor necrosis factor- $\alpha$ and interleukin-1 $\beta$ in first trimester human decidual cells: implication for preeclampsia. Am J Pathol 168:445-452. 
Madsen G, Zakar T, Ku CY, Sanborn BM, Smith R \& Mesiano S (2004) Prostaglandins differentially modulate progesterone receptor $\mathrm{A}$ and $-\mathrm{B}$ expression in human myometrial cells: evidence for prostaglandin-induced functional progesterone withdrawal. J Clin Endocrinol 89:1010-13.

Mansour I, Reznikoff-Etievant MF \& Netter A (1994) No evidence for the expression of the progesterone receptor on peripheral blood lymphocytes during pregnancy. Hum Reprod 9:1546-1549.

Mastorakos G \& Ilias I (2000) Maternal hypothalamic-pituitary-adrenal axis in pregnancy and the postpartum period. Ann NY Acad Sci 900:95-106.

Meis P, Klebanoff M, Thom E, Dornbrowski MP, Sibai B, Moawad AF, et al (2003) Prevention of recurrent preterm delivery by 17 alpha-hydroxyprogesterone caproate. New England J Med 348:2379-2385.

Mesiano S, Chan EC, Fitter JT, Kwek K, Yeo G \& Smith R (2002) Progesterone withdrawal and estrogen activation in human parturition are coordinated by progesterone receptor A expression in the myometrium. J Clin Endocrinol Metab 87:2924-2930.

Mesiano S (2007) Myometrial progesterone responsiveness. Semin Reprod Med 25:5-13.

Miyaura H \& Iwata M (2002) Direct and indirect inhibition of Th1 development by progesterone and glucocorticoids. J Immunol 168: 1087-1094.

Molnar M, Rigo J Jr, Romero R \& Hertelendy F (1999) Oxytocin activates mitogen-activated protein kinase and up-regulates cyclooxygenase-2 and prostaglandin production in human myometrial cells. Am J Obstet Gynecol 181:42-49.

Mulac-Jericevic B \& Conneely OM (2004) Reproductive tissue selective actions of progesterone receptors. Reproduction 128:139-146.

Norman M, Ekman G \& Malmström A (1993) Changed proteoglycan metabolism in human cervix immediately after spontaneous vaginal delivery. Obstet Gynecol $81 ; 217-223$.

Norman AW, Mizwicki MT \& Norman DP (2004) Steroid-hormone rapid actions, membrane receptors and a conformational ensemble model. Nature Rev 3: 27-41.

Norwitz ER, Starkey P, Lopez Bernal A \& Turnbull A (1991) Identification by flow cytometry of the prostaglandin-producing cells of term human decidua. J Endocrinol 131:327-334.

O’Brien JM, Adair CD, Lewis DF, Hall DR, deFranco EA, Fusey P, et al (2007) Progesterone vaginal gel for the reduction of recurrent preterm birth: primary results from a randomised, double blind, placebo-controlled trial. Ultrasound Obstet Gynecol 30: 687-696.

O’Malley B (1990) The steroid receptor superfamily. More excitement predicted for the future. Mol Endocrinol 4:363-369.

Piccinni MP, Giudizi MG, Biagiotti R, Beloni L, Giannarini L, Sampognaro S, et al (1995) Progesterone favours the development of human $\mathrm{T}$ helper cells producing Th2-type cytokines and promotes both IL-4 production and membrane CD30 expression in established Th1 cell clones. J Immunol 155:128-133.

Piccinni MP (2010) T cell tolerance towards the fetal allograft. J Reprod Immunol 85:71-75. Review. 
Pieber D, Allport VC, Hills F, Johnson M, Bennett PR (2001) Interaction between progesterone receptor isoforms in myometrial cells in human labor. Mol Hum Reprod 7:875-879.

Romero R, Scoccia B, Mazor M, Wu YK \& Benaviste R (1988) Evidence for a local change in the progesterone/estrogen ratio in human parturition at term. Am J Obstet Gynecol 159:657-660.

Romero R (2007) Prevention of spontaneous preterm birth: the role of sonographic cervical length in identifying patients who may benefit from progesterone treatment. Ultrasound Obstet Gynecol 30 :675-686.

Rook GA, Hernandez-Pando R \& Lightman SL (1994) Hormones, peripherally activated prohormones and regulation of the Th1/Th2 balance. Immunol Today 13:301303.

Rupnow HL, Phernetton TM, Modrick ML, Wiltbank MC, Bird IM \& Magness RR (2002) Endothelial vasodilator production by uterine and systemic arteries. VIII. Estrogen and progesterone effects on CPLA2, COX-1, and PGIS protein expression. Biol Reprod 66:468-474.

Sanborn BM, Held B \& Kuo HS (1976) Hormonal action in human cervix - II Specific progestogen binding proteins in humans. J Ster Biochem 7:665-672.

Schindler AE, Campagnoli C, Druckmann R, Huber J, Pasqualini JR, Schweppe KW \& Thijssen JH (2003) Classification and pharmacology of progestins. Maturitas Suppl 1: S7-S16.

Schwalm H \& Dubrauszky V. The structure of the musculature of the human uterus muscles and connective tissue (1966) Am J Obstet Gynecol 94:391-404.

Sennström M, Ekman G, Westergren-Thorsson G, Malmström A, Byström B, Endresen U et al (2000) Human cervical ripening, an inflammatory process mediated by cytokines. Mol Hum Reprod 6:375-381.

Speroff L, Glass \& Kase N, eds (1994) Clinical gynecologic endocrinology and infertility (5 $5^{\text {th }}$ Edition) Williams and Wilkins, USA.

Stites DP \& Siiteri PK (1983) Steroids as immunosuppressants in pregnancy. Immunol Rev 75:117-138.

Stjernholm Y, Sahlin L, Malmström A, Barchan K, Eriksson HA \& Ekman G (1997) Potential roles for gonadal steroids and insulin-like growth factor I during final cervical ripening. Obstet Gynecol 90:375-380.

Stout RD \& Suttles J (2004) Functional plasticity of macrophages: reversible adaptation to changing microenvironments. J Leukoc Biol 76:509-513.

Stygar D, Wang H, Vladic Stjernholm Y, Ekman G, Eriksson HA \& Sahlin L (2002) Increased levels of matrix metalloproteinases 2 and 9 in the ripening process of the human cervix. Mol Hum Reprod 67:889-894.

Sugimoto Y, Yamasaki A, Segi E, Tsuboi K, Aze Y, Nishimura T, et al (1997) Failure of parturition in mice lacking the prostaglandin F receptor. Science 277:681-683.

Szekeres-Bartho J, Kilar F, Falkay G, Csrnus V, Torok A \& Pacsa AS (1985) Progesteronetreated lymphocytes of healthy pregnant women release a factor inhibiting cytotoxicity and prostaglandin synthesis. Am J Reprod Immunol Microbiol 9:1519. 
Szekeres-Bartho J, Szekeres G, Debre P, Autran B \& Chaouat G (1990) Reactivity of lymphocytes to a progesterone receptor-specific monoclonal antibody. Cell Immunol 125:273-283.

Szekeres-Bartho J (2002) Immunological relationship between the mother and the fetus. Int Rev Immunol 21:471-495.

Tibbetts TA, de Mayo F, Rich S, Conneely OM \& O’Malley B (1999) Progesterone receptors in the thymus are required for for thymic involution during pregnancy and for normal fertility. Proc Natl Acad Sci USA 96:12021-6.

Tucker HA (1979) Endocrinology of lactation. Semin Perinatol 3: 199-223.

Uldbjerg N, Ekman G, Malmström A, Olsson K \& Ulmsten U (1983) Ripening of the human uterine cervix is related to changes in collagen, glycosaminoglycans and collagenolytic activity. Am J Obstet Gynecol 147:662-666.

Vacca A, Martinotti S, Screpanti I, Maroder M, Felli MP, Farina AR, et al (1990) Transcriptional regulation of the interleukin 2 gene by glucocorticoid hormones. J Biol Chem 265: 8075-8080.

Vegeto E, Shahbaz MM, Wen DX, Goldman ME, O'Malley BW \& McDonnell DP (1993) Human progesterone receptor A form is a cell- and promoter specific repressor of human progesterone receptor B function. Endocrinology 7:1244-1255.

Wegmann TG, Lin L, Guilbert L \& Mosmann TR (1993) Bidirectional cytokine interactions in the maternal-fetal relationship: is successful pregnancy a Th2 phenomenon? Immunol Today 14:353-356.

Weiner LH (2001) Induction and mechanism of action of transforming growth factor beta secreting Th3 regulatory cells. Immunol Rev 182:207-214.

White HD, Yeaman G, Givan A \& Wira C. Mucosal immunity of the female reproductive tract: cytotoxic $\mathrm{T}$ lymphocyte function in the cervix and vagina of premenopausal and postmenopausal women (1997) Am J Reprod Immunol 37:30-38.

WHO (1977) recommended definitions, terminology and format for statistical tables related to the perinatal period and use of a new certificate for cause of perinatal deaths. Modifications recommended by FIGO as amended October 14, 1976. Acta Obstet Gynecol Scand 56(3):247-253.

Winkler M, Kemp B, Fischer DC, Ruck P \& Rath W (2003) Expression of adhesion molecules in the lower uterine segment during term and preterm parturition. Microsc Res Tech 1:430-444.

Vladic Stjernholm Y, Wang H, Stygar D, Ekman G \& Sahlin L (2004) Differential regulation of the progesterone receptor $\mathrm{A}$ and $\mathrm{B}$ in the human uterine cervix. Gynecol Endocrinol 18:41-46.

Vladic Stjernholm Y, Vladic T, Blesson CS, Ekman-Ordeberg G \& Sahlin L (2009) Prostaglandin treatment is associated with a withdrawal of progesterone and androgen at the receptor level in the uterine cervix. Reprod Biol Endocrinol 7:116.

Wolfe LA, Kemp JG, Heenan AP, Preston RJ \& Ohtake PJ (1998) Acid-base regulation and control of ventilation in human pregnancy. Can J Physiol Pharmacol 76: 815-827. 
Wood GW, Hausmann E \& Choudhuri R (1997) Relative role of CSF-1, MCP-1/JE, and RANTES in macrophage recruitment during successful pregnancy. Mol Reprod Dev 46:62-70.

Zhu Y, Bond J \& Thomas P (2003) Identification, classification, and partial characterization of genes in humans and other vertebrates homologous to a fish membrane progestin receptor. Proc Natl Acad Sci USA 100:2237-2242. 


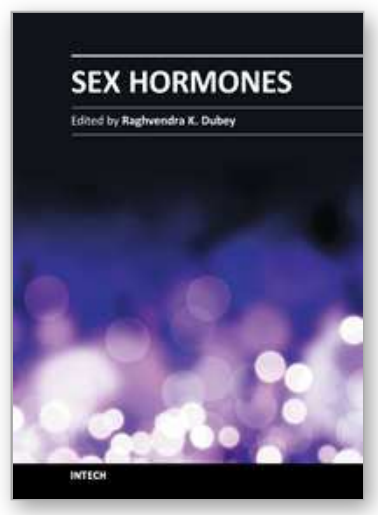

\section{Sex Hormones}

Edited by Prof. Raghvendra Dubey

ISBN 978-953-307-856-4

Hard cover, 430 pages

Publisher InTech

Published online 08, February, 2012

Published in print edition February, 2012

Sex Hormones not only regulate reproductive function, but they also play a prominent role in the biology and physiology of several organs/tissues and in the pathophysiology of several diseases. During the last two decades, the information on the mechanisms of action of sex hormones, such as estrogens and androgens, has rapidly evolved from the conventional nuclear receptor dependent mechanisms to include additional nonnuclear, non-genomic and receptor-independent mechanisms. This highlights the need to update the current knowledge on sex hormones and their mode of action. Increasing evidence that exogenous/epigenetic factors can influence sex hormone production and action highlights the need to update our knowledge on the mechanisms involved. This book provides a systematic and updated overview of the male/female sexhormones and their impact in the biology and physiology of various organs. Additionally, the book discusses their positive and negative association with the pathophysiology of various diseases (e.g. osteoporosis, cardiovascular-disease, hypogonadism, reproduction, cancer) and their therapeutic potential.

\section{How to reference}

In order to correctly reference this scholarly work, feel free to copy and paste the following:

Ylva Vladic Stjernholm (2012). Progesterone in Human Pregnancy and Parturition, Sex Hormones, Prof. Raghvendra Dubey (Ed.), ISBN: 978-953-307-856-4, InTech, Available from:

http://www.intechopen.com/books/sex-hormones/progesterone-in-pregnancy-and-parturition

\section{INTECH}

open science | open minds

\section{InTech Europe}

University Campus STeP Ri

Slavka Krautzeka 83/A

51000 Rijeka, Croatia

Phone: +385 (51) 770447

Fax: +385 (51) 686166

www.intechopen.com

\section{InTech China}

Unit 405, Office Block, Hotel Equatorial Shanghai No.65, Yan An Road (West), Shanghai, 200040, China 中国上海市延安西路65号上海国际贵都大饭店办公楼405单元 Phone: +86-21-62489820

Fax: $+86-21-62489821$ 
(C) 2012 The Author(s). Licensee IntechOpen. This is an open access article distributed under the terms of the Creative Commons Attribution 3.0 License, which permits unrestricted use, distribution, and reproduction in any medium, provided the original work is properly cited. 